\title{
A review: medicinal values, agronomic practices and postharvest handlings of Vernonia amygdalina
}

\author{
Nursuhaili, A.B., Nur Afiqah Syahirah, P., *Martini, M.Y., Azizah, M. and \\ Mahmud, T.M.M.
}

Department of Crop Science, Faculty of Agriculture, Universiti Putra Malaysia, 43400 Serdang, Selangor, Malaysia

\author{
Article history: \\ Received: 15 November 2018 \\ Received in revised form: 10 \\ February 2019 \\ Accepted: 10 February 2019 \\ Available Online: 19 \\ February 2019
}

Keywords:

Vernonia amygdalina,

Medicinal uses,

Phytochemical content,

Agronomic practices,

Postharvest handlings

DOI:

https://doi.org/10.26656/fr.2017.3(5).306

\begin{abstract}
Recently, researchers are aiming to discover a new source of therapeutic substance produced organically with no harm or possible toxicity to humans, environment and even to animals. Herbal plant-based approach is one of the options available since organic herbal products are gaining popularity around the world as food supplements. Regarding on the commercialization of herbal plants, cultivation of raw materials with standardized farming practices is crucial to achieve the consistency of its quality to fulfill the market demand. Vernonia amygdalina, is one of the herbal plants, commonly known as 'Pokok Bismillah' from Asteraceae family, having valuable medicinal properties due to the presence of phytochemical compounds for treating various diseases. There exists scarce information on appropriate agronomic practices for the cultivation of this plant either in small or commercial scale. Therefore, this review collates current knowledge in appropriate agronomic practices and postharvest handlings in order to achieve optimum growth and yield with high medicinal properties of Vernonia amygdalina.
\end{abstract}

\section{Introduction}

Vernonia amygdalina, known as 'Pokok Bismillah', is a perennial shrub from Asteraceae family and also commonly called 'Bitter Leaf' because of bitter taste of its leaves. Not only named Bitter Leaf, this plant also has a lot of other local names in different languages of the different regions of the world, such as Ewuro, Onugbu, Oriwo, Etidot and Ityuna in Nigeria, Mululuza and Omubirizi in Uganda, Ebichaa in Ethiopia and Awonwono in Ghana (Yineger and Yewhalaw, 2007; Moshi et al., 2010; Farombi and Owoeye, 2011; Komlaga et al., 2015; Kiguba et al., 2016). Even in Malaysia, this plant is called South African leaf. As the largest genus among Vernoniae tribe, Vernonia has close to 1000 species in its family (Keeley and Jones, 1979). The genus Vernonia gets its name after an English botanist, William Vernon who identified the plant in Maryland, in the late 1600s before his death in 1711 (Quattrocchi, 1999).

This herb has been domesticated in many parts of West Africa, but grows freely in tropical Africa (Igile et al., 1994). However, it is also well distributed in Asia (Oseni and Babatunde, 2016). Although it is well distributed in Asia, Nigerians are more aware about its benefit and have been utilizing this plant to its maximum usage as it has many health benefits compared to other regions. As a home-grown plant, Vernonia species can easily adapt to different environments according to its habitat. They are generally found in natural forests where easy water access is available. They also can easily be found in forest margins, woodlands and grasslands up to 2,800 $\mathrm{m}$ in altitude, with mean annual rainfall 750-2000 $\mathrm{mm}$. Ndaeyo (2007) reported that even though $V$. amygdalina was more prone to humid environment, it could also tolerate drought and grow very well on all types of soil. However, it grows better on humus-rich soil. This explains why this plant has an amazing survival ability in such a wide range of ecological zones.

\subsection{Morphological characteristics}

$V$. amygdalina is a perennial soft wooded shrub (Yeap et al., 2010) (Figure 1a) that can reach up to $10 \mathrm{~m}$ in height with $40 \mathrm{~cm}$ stem diameter. The bark is densely pubescent at the young stage, as the plant gets matured, the bark turns to grey then to brown in colour, smooth, and disclosed. The leaves are arranged alternately with each other, simple with 0.2 to $4 \mathrm{~cm}$ long petioles. The leaf blade is ovate-elliptical to lanceolate and measures 4 $-15 \mathrm{~cm} \times 1-4 \mathrm{~cm}$, cuneate or rounded at base, shortly acuminated at the apex of the leaves and the margins are clearly toothed to coarsely serrate, finely pubescent but 
often glabrescent (Figure 1d). The inflorescence of this plant is in the form of head, arranged in terminal, compound, and umbel-like cymes. The head stalk measures about $1 \mathrm{~cm}$ long and pubescent. The flowers are bisexual, regular, strongly exerted from the involucres which are cylindrical to broadly ellipsoid (Figures $1 \mathrm{~b}$ and $1 \mathrm{c}$ ). As the flower developed into fruit, the fruit is a 10-ribbed achene measuring $1.5-3.5 \mathrm{~mm}$ long, pubescent and glandular and brown to black in colour, crowned by a much longer (Grubben, 2004).

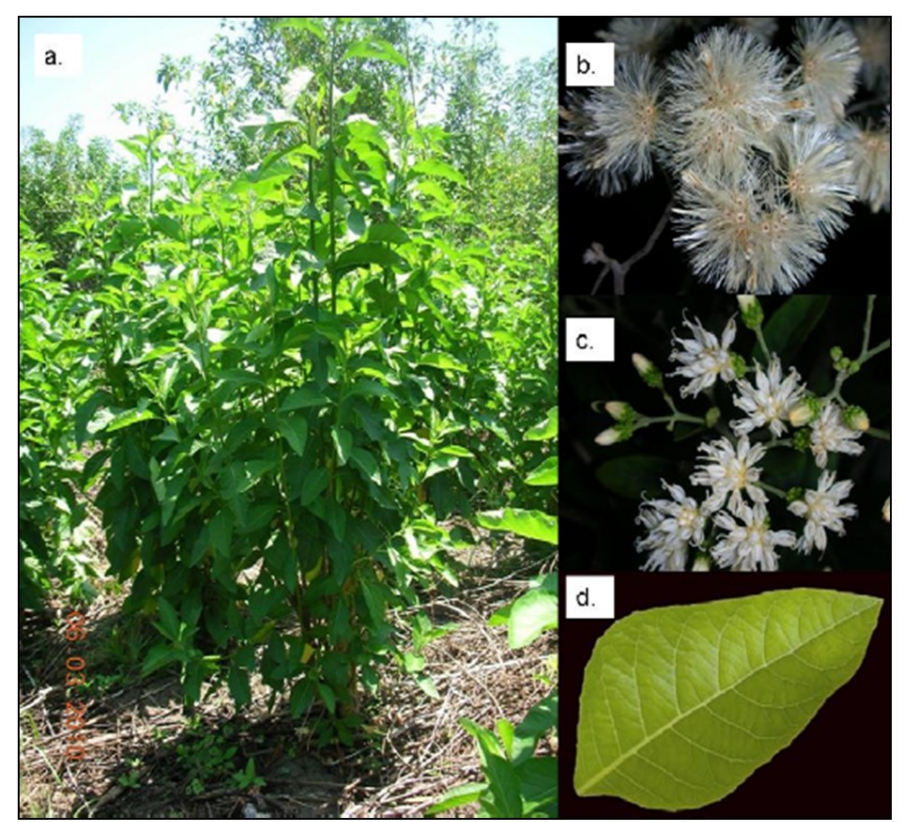

Figure 1. 1a: Photos of $V$. amygdalina. $1 \mathrm{~b}$ and 1c: $V$. amygdalina flowers. 1d: A leaf of V. amygdalina (Yeap et al., 2010).

\subsection{Main uses}

Bitter herb is described as good for the body as it assists the crucial organs of the body such as kidney and liver. Traditionally, old folks believe that the bitterness of a plant is related to its medicinal properties, with potential medicinal values. The same goes for $V$. amygdalina, there are many reports on its medicinal properties. However, due to the lack of modern medicine, indigenous people of many countries make use of this plant to cure diseases. They would make use of the plant parts, mostly leaves, either extracting it into juice, ingesting it or applying it externally. Presently, some methods are found to give positive response that eventually cure the disease.

Not only that, due to cultural and economic reasons, some people especially in Africa utilize this plant for health purpose. In Nigeria, the plant is made into tonic for medicinal purposes. To get rid of the bitter taste, the leaves of $V$. amygdalina are used as soup condiments after the leaves are washed and boiled (Hamzah et al., 2013). This method is used specially to prepare bitter leaf soup, 'Onugbo' a popular Nigerian dish (Ho et al.,
2012)

V. amygdalina has many nutritive properties that can cure some diseases. Compared to other plant parts, leaves are the most used in disease treatment such as hypertension, measles, constipation, induction of uterine mobility, control of post-partum hemorrhage, fever, viral disease, hypercholesterolemia, voluntary skin depigmentation, emesis, nausea, loss of appetite-induced ambrosia, schistomiasis, amoebic dysentery and other gastrointestinal tract problems (Huffman et al., 1996; Francis, 2015). It is also used to cure malaria, venereal diseases, wounds, hepatitis, jaundice, tuberculosis and diabetes (Riley, 1963; Chagnon, 1984; Vlietinck et al., 1995; Akah and Ekekwe, 1995; Hamill et al., 2000; Kambizi and Afolayan, 2001; Munaya, 2013).

Not restricted to humans, this plant can be applied to animals too for the treatment of many animal diseases. Exploitation of $V$. amygdalina as herb in animal use begin when a zoo pharmacologist found out that sick chimpanzees with empty stomach sucked out pith and juice from the unsavory Vernonia plant stalk. This incident caught many attentions as Vernonia was not a common diet for the chimpanzees because of its bitterness. The bitter taste of this plant is suspected as a guide for the chimpanzees to do self-deparasitization, enhance body fitness and appetite, and reduce constipation or diarrhea specifically during rainy season (Huffman and Seifu, 1989; Clayton and Wolfe, 1993; Jisaka, Ohigashi, Takegawa, Hirota et al., 1993; Jisaka, Ohigashi, Takegawa, Huffman et al., 1993; Koshimizu et al., 1994; Huffman et al., 1997). In another instance in Northern Nigeria, this plant was made into strengthening or fattening tonic called 'Chusan Dokin' (Hamzah et al., 2013).

\subsection{Other uses}

Besides, because of its huge stem diameter, this plant also has been widely used as fuel wood, stakes, and fodder and construction poles. Furthermore, this plant can also be used as live fencing of agroforestry buffer zone as it can grow tall up to $10 \mathrm{~m}$ high. $V$. amygdalina is utilized as an ingredient for composting purpose. Due to its bitterness, it can be used as a bittering agent, a hop substitute and for the control of microbial contamination in beer brewing without affecting the quality of malt. In Ethiopia, it is used to make honey wine called 'Tei' (Kasalo and Temu, 2008).

\subsection{Benefits of $V$. amygdalina}

\subsubsection{Antibacterial properties}

$V$. amygdalina leaves are the most used part for extraction which has been shown to exhibit an inhibitory effect on both Gram-positive Staphylococcus aureus and 
Gram-negative Escherichia coli bacteria (Oboh and Enobhayisobo, 2009). This is also supported by Udochukwu et al. (2015) that both of these bacteria showed sensitivity towards $V$. amygdalina extract as they gave out $0.8 \mathrm{~cm}$ zone of exhibition.

Meanwhile, extract of $V$. amygdalina by water and ethanol exhibited antibacterial activity against pure culture of clinical bacterial isolates such as Pseudomonas aeruginosa, Klebsiella spp., Streptococcus spp., and Candida albicans (Ghamba et al., 2014). In addition, acetone extract of this plant had indicated antibacterial activity against Bacillus cereus, Bacillus pumilus, Bacillus subtilis, Micrococcus kristinae, Enterobacter cloacaem, E. coli and Staphylococcus aureus (Kambizi and Afolayan, 2001).

Not only the leaf extract of $V$. amygdalina but its root water extract also possessed antibacterial activity against Streptococcus gordonii, Porphyromonas gingivalis, Porphyromonas nigrescens, Prevotella intermedia, Fusobacterium nucleatum and $P$. aeruginosa at minimum inhibitory concentration of $100 \mathrm{mg} / \mathrm{mL}$ (Taiwo et al., 1999).

The peeled stem of $V$. amygdalina can be used as chewing stick for teeth cleaning purposes and it was reported to be very active as it contributed to anticaries, gum healing, antisickling, haemostasis; to stop the blood flow and antimicrobial activity and plaque inhibiting effect (Etkin, 2002; Adekunle, 2002).

\subsubsection{Antifungal properties}

Antifungal activity in $V$. amygdalina is concentrated more on its water extract. Leaf water extract of this plant was shown to inhibit growth of Fusarium moniliforme on maize seed and growth of conidia and mycelia of Collectotrichum gleosporiodes in rubber trees (Owolade et al., 2000; Ogbebor et al., 2007; Suleiman et al., 2008). In pepper, cold water extract of stem and root barks was able to suppress growth of Collectotrichum capcici that can cause leaf blight disease (Nduagu et al., 2008).

Infection of Sclerocium rolfii, a causal agent for Southern blight disease in cowpea can be controlled by using hot water extract of $V$. amygdalina. Not only it can suppress growth of mycelia, but the extract also can enhance physical growth of cowpea plant including number of pods per plant, weight and grain yield. Physiologically, phytotoxic effect of the extract will be induced where it reduces the recoverable of photosynthesis and transpiration rate of the treated plant. This can be used to preserve high water content in seedlings of cowpea via antitranspirants during the dry season for its survival (Alabi et al., 2005).
Strong antifungal activity against Pseudoperonospora cubensis and moderate activity against Rhizoctonia solani were expressed by methanol extract of $V$. amygdalina (Ohigashi et al., 1991). Furthermore Enikuomehin et al. (1998) reported that the ash from $V$. amygdalina also contained antifungal activity as it was found to suppress mycelial growth of Sclerotium rolfsii Sacc. The ash also protected the seed from post-emergence infection through inhibition of fungal growth within the roots and crown zone. High nitrogen level in the ash of $V$. amygdalina was the sole reason why it could inhibit growth of $S$. rolfsii Sacc (Enikuomehin et al., 1998). However, leaf extract of $V$. amygdalina could be metabolized by Mycospharella fijiensis, causal agent for Black sigatoka disease in banana for growth and sporulation induction (Okigbo and Emoghene, 2003). The ash from $V$. amygdalina also possesses antifungal property which has reported to retard mycelial growth of $S$. rolfsii Sacc on wheat and seedlings (Enikuomehin et al., 1998).

\subsubsection{Antioxidant properties}

Any substance that slows down or inhibits oxidative damage to a target molecule can be called antioxidant (Yamagishi and Matsui, 2011). The primary characteristic that an antioxidant has is its ability to entrap free radicals such as peroxide, hydroperoxide or lipid peroxyl and inhibit the oxidative mechanism that then will lead to degenerative disease (Wu et al., 2011). Most of the time, it is believed that herbal plants have good antioxidant activities and that could be the reason that all of the supplements and medicine are extracted from them.

From DPPH radical scavenging test, ethanol extract of $V$. amygdalina was shown to have antioxidant activity (Ayoola et al., 2008). When compared to vernodalol and vernolide at $250 \mu \mathrm{g} / \mathrm{mL}$, ethanol extract of $V$. amygdalina showed the highest reducing capacity and DPPH radical scavenging activity effect (Erasto et al., 2007a). From the root of $V$. amygdalina, DPPH radical scavenging activity was compared among the different extracts at $1 \mu \mathrm{g} / \mathrm{ml}$ concentration, and ethanol extract was found to inhibit $77 \%$ of scavenging activity followed by hot and cold-water extracts with $63 \%$ and $49 \%$ of scavenging activity, respectively. It was found that all of the extracts were able to inhibit bleaching of $\beta$-carotene, oxidation of linoleic acid and lipid peroxidation induced by $\mathrm{Fe}^{2+}$ /ascorbate in a rat liver microsomal preparation (Owolabi et al., 2008; Khalafalla et al., 2009). However, methanol extract gave the highest antioxidant activity compared to acetone and water extracts (Erasto et al., 2007b). This could probably be due to the methanol extract been capable of protecting the stability of the 
membrane in the hemagglutination test (Iwalewa et al., 2005).

Drying, boiling and blanching are common process carried out during extraction of $V$. amygdalina. However, these processes tended to reduce the ascorbic acid content in the plant (Oboh and Akindahunsi, 2004; Oboh, 2005; Odukoya et al., 2007). Free radical scavenging activity and toxicity of $V$. amygdalina and reducing capacity were also reduced by blanching process (Oboh, 2005) but the total phenolic content, reducing power and free radical scavenging ability of the plant were increased. This indicates that in $V$. amygdalina, vitamin $\mathrm{C}$ does not act as an important antioxidant agent (Yeap et al., 2010).

\subsection{Chemical composition}

\subsubsection{Phytochemicals content}

In relation to phytochemicals content, a study conducted by Usunobun and Ngozi (2016) found that saponins, tannins, alkaloids and flavonoids, triterpenoids, steroids and cardiac glycosides were high in $V$. amygdalina which served as a great source of pharmacologically active phytochemicals and effective as supplements in human and animal nutrition.

More than thirty compounds belonging to several classes of compounds with different bioactives have been isolated and characterized from $V$. amygdalina. Compounds such as vernolide, vernodalol, vernodalin and hydrxyvernolide can be used for antimicrobial, antioxidant, antitumoral and antischistosomal agents. There are also several compounds in this plant that are useful in fighting cancerous cells, such as vernodalinol, vernomygdin, and epivernodalol. 11, 13Dihydrovernodalin can be used for anti-feed pesticide, to prevent pests from feeding. All these compounds come from sesquiterpene lactone class (Kupchan et al., 1969; Owoeye et al., 2010; Luo et al., 2011) Luteolin, Luteolin -7-O- $\beta$-glucuronoside, Luteolin-7-O- $\beta$-glucoside that comes from flavonoid class can be used as antioxidant (Igile et al., 1995).

On the other hand, steroid saponins compound class that have Vernoamyosides A, B, C and D are useful as anti-inflammatory agents (Quasie et al., 2016). Extraction of this plant has to be standardized to ensure the quality of the product derived from this plant such as alternative medicine in disease treatment (Oyeyemi et al., 2018). This is because, compared to the parent plant, phytochemical activities seem to be less in individual isolated compounds as several isolated compounds have shown one or more of the activities exhibited by the plant itself. This means that the activities by the plant happened because of synergic reactions of the individual components.

\subsubsection{Nutritional content}

Proximate composition of $V$. amygdalina reveals the presence of protein $(62.2 \%)$, crude carbohydrate $(22 \%)$, ash $(9.95 \%)$, crude fibre $(16 \%)$ and crude fat $(3.45 \%)$ as reported by Nwaoguikpe (2010) (Figure 2). High ash content has been found by Yeap et al. (2010) and this reflected that $V$. amygdalina leaves contain useful mineral contents. This herb rich in mineral elements including chlorine, copper, ferum, potassium, manganese, nickel, sodium, sulphur (Yeap et al., 2010) phosphorus, calcium, potassium, magnesium, zinc, iron and some vitamins such as Vitamin A, C and E (Nwaoguikpe, 2010).

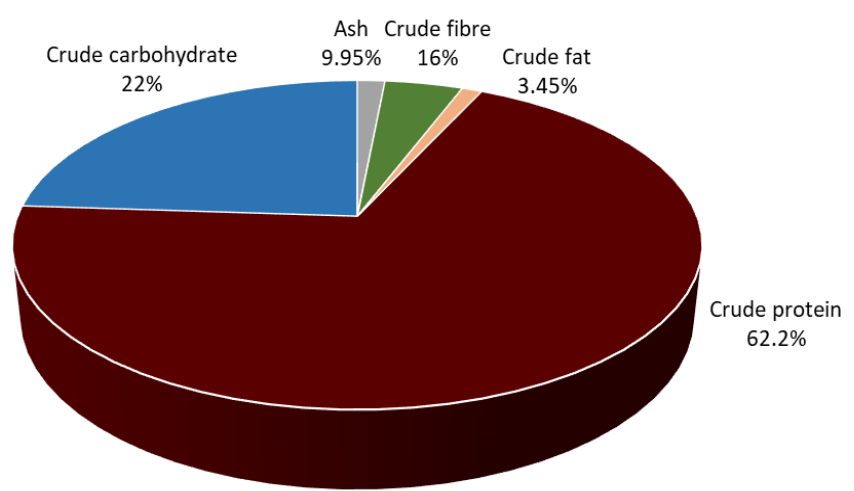

Figure 2. Proximate composition of nutritional value of $V$. amygdalina. Adapted from Nwaoguikpe (2010); Yeap et al. (2010)

The mineral contents of potassium, zinc, calcium, manganese and chromium are believed to possess beneficial effect in the treatment of diabetes mellitus (Marles and Farnsworth, 1995). Potassium and calcium play important roles to control the glucose level as they help to maintain the normal glucose-tolerance in the human body (Kadiri and Olawoye, 2016) (Table 1). Besides, high sulphur concentration in this herb is essential for detoxification of cyanide while low sodium content is suitable for obese patients (Ifon and Bassir, 1979). While the vitamins act as antioxidant and able to protect the tissues or cells of the diabetic patients against degenerative changes associated with the sydrome (Fasuyi et al., 2006).

Table 1. Mineral composition of $V$. amygdalina $(\mathrm{mg} / 100 \mathrm{~g}$ dry matter)

\begin{tabular}{ccccc}
\hline Calcium & Phosphorus & Iron & Zinc & Manganese \\
\hline 145.0 & 6.7 & 5.0 & 85.0 & 710.0 \\
\hline
\end{tabular}

Adapted from Kadiri and Olawoye (2016)

On the other hand, high sugar (raffinose, lactose, sucrose, glucose, galactose, fructose, maltose and arabinose), vitamin (thiamine, nicotinamide, thiamine, riboflavin, pyridoxine and ascorbic acid), casein 
hydrolysate, amino acids (non-essential amino acid: cysteine, glycine and essential amino acid: leucine, valine and phenylalanine), less acid value $(10 \mathrm{mg} / 100 \mathrm{~g}$ dry matter) and high iodine $(35 \mathrm{mg} / 100 \mathrm{~g})$ value have promoted $V$. amygdalina as a popular vegetable in Africa and has been proposed as potential agent in treating goiter (Yeap et al., 2010).

\section{Production and cultivation}

$V$. amygdalina is an important vegetable in Cameroon, where out of 93,600 tons of leafy vegetables harvested in 1998, 23\% (21,549 tons) was bitter leaf. For instance, Nigeria is a main producer of the health products based on $V$. amygdalina and its derivative products have been commercialized as EdoBotanics, EdoTide Plus and Diabetes 5 (Yeap et al., 2010).

\subsection{Preparation of cuttings}

Propagation of this herb is usually through stem cuttings of mature plants ( $>1$ year old mother plants) by the farmers, however it does not produce seeds in normal circumstances (Yeap et al., 2010). The stem cuttings of $V$. amygdalina of $15 \mathrm{~cm}$ long (4-5 nodes) taken from the middle parts of a mother plant could be the most suitable planting material (Figure 3). It should be propagated in humus-rich soil (ratio 3:2:1 cocopeat: sand) to trigger high root formation. It grows well under shaded environment to reduce excessive sunlight exposure (Ucheck Fomum, 2004). However, some studies found that the white, fragrant and bee-infested flowers growing under drastic growth environment and the seeds from dried flower heads could thrive well in slightly acidic soil with low organic matter and high-water holding capacity (Kayode, 2004).

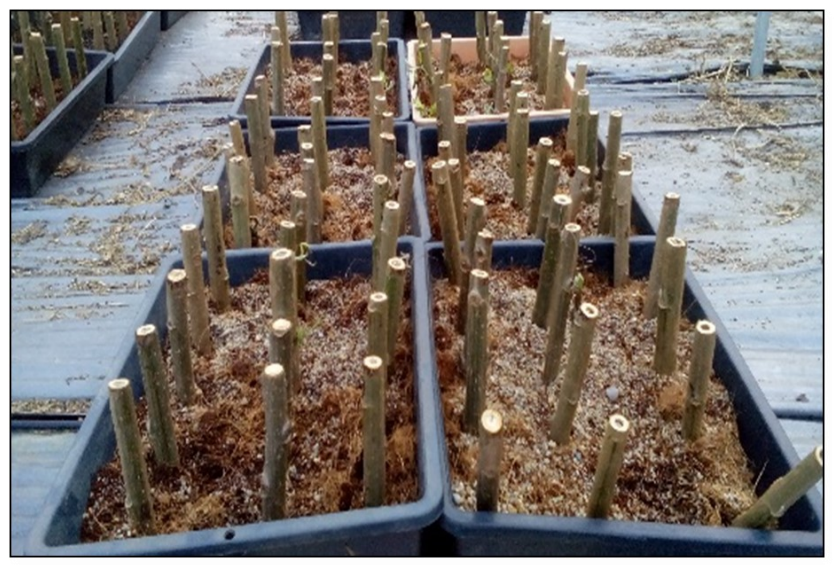

Figure 3. Propagation of $V$. amygdalina by stem cuttings after one day propagation. Picture taken from Field 15, Universiti Putra Malaysia, Serdang, Selangor.

\subsection{Field preparation}

The growing media in the polybags were prepared by following the ratio of $3: 2: 1$ (soil: organic matter: sand). The organic matter of empty fruit bunch (EFB) could be applied as a soil amandement. The growing media with the combination of soil: EFB: sand was mixed and transferred into polybags $(41 \times 41 \mathrm{~cm})$.

\subsection{Planting}

The rooted cuttings are transplanted to the field after a month (Figures 4 and 5). The cuttings can be planted erect or slanting at $45^{\circ}$ angle to obtain more side-shoots (Ucheck Fomum, 2004). Normally, the cuttings are planted directly on the field or into polybags to a depth of $3 \mathrm{~cm}$. While, seeds take 2-3 weeks to germinate before transplant to the field after 4-6 weeks after emergence (Ucheck Fomum, 2004).

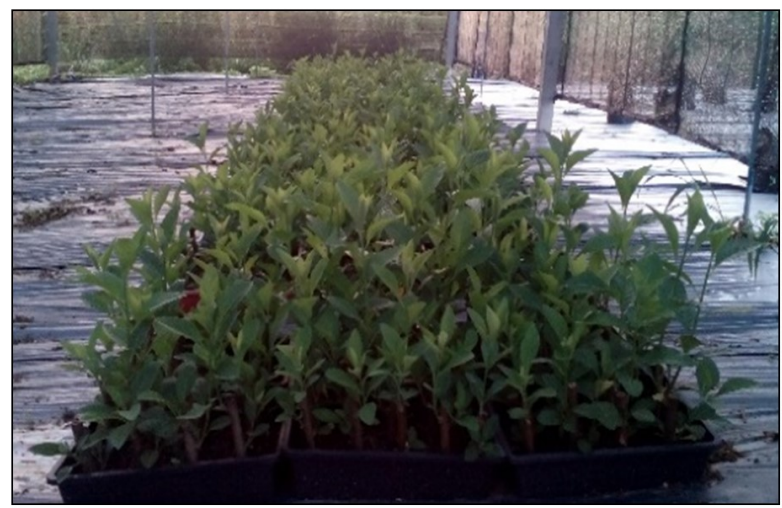

Figure 4. Seedlings of $V$. amygdalina during propagation under shade house after a month. Picture taken from Field 15, Universiti Putra Malaysia, Serdang, Selangor.

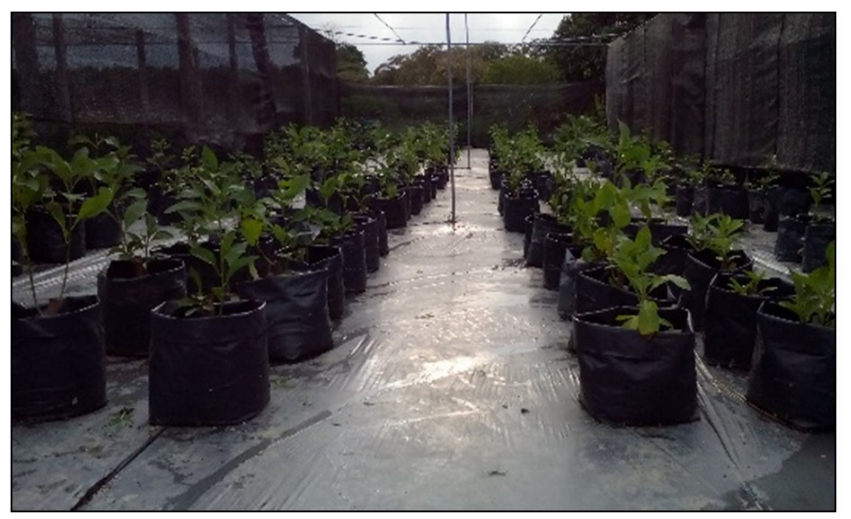

Figure 5. Rooted cuttings of $V$. amygdalina transplanted into polybags. Picture taken from Field 15, Universiti Putra Malaysia, Serdang, Selangor.

\subsection{Fertilization}

The application of $\mathrm{N}$ based fertilizer at the rate of 30 $\mathrm{mg} \mathrm{N} / \mathrm{kg}$ soil: $30 \mathrm{mg} \mathrm{P}_{2} \mathrm{O}_{5} / \mathrm{kg}$ soil: $22 \mathrm{mg} \mathrm{K} \mathrm{K}_{2} \mathrm{O} / \mathrm{kg}$ soil or without $\mathrm{N}$ based fertilizer with similar rates can be applied on $V$. amygdalina (Musa et al., 2011). Organic fertilizer such as chicken manure can also be applied at the rate of 2 tons per hectare, once a month.

\subsection{Field management}

Weeding and mulching in the nursery stage contribute to healthy and rapid growth of seedlings and 
cuttings of $V$. amygdalina. A regular supply of moisture is important, and irrigation is necessary during dry season. Normally, the plants need to be watered twice daily (morning and evening) to trigger plant growth and development (Musa et al., 2011). Water is the key factor for the growth of $V$. amygdalina leaves. Therefore, high yield can be produced during rainy season (Yeap et al., 2010). The pruning of old branches should be done in order to stimulate abundant foliage. This is best done before the rainy season, whereby it only takes 3 weeks for fresh shoots to develop after pruning (Ucheck Fomum, 2004).

\subsection{Harvest time}

$V$. amygdalina is a short cycle crop which it can be harvested twice per month for up to seven years (Yeap et al., 2010) by pruning the leafy shoots to allow new side shoots to develop, which they can be harvested a few weeks later (Ucheck Fomum, 2004). However, harvesting of $V$. amygdalina at 3 weeks intervals resulted that 9 and 18 weeks after sowing could be the best time in order to obtain the desirable yield as well as high phytochemicals content.

\subsection{Pests}
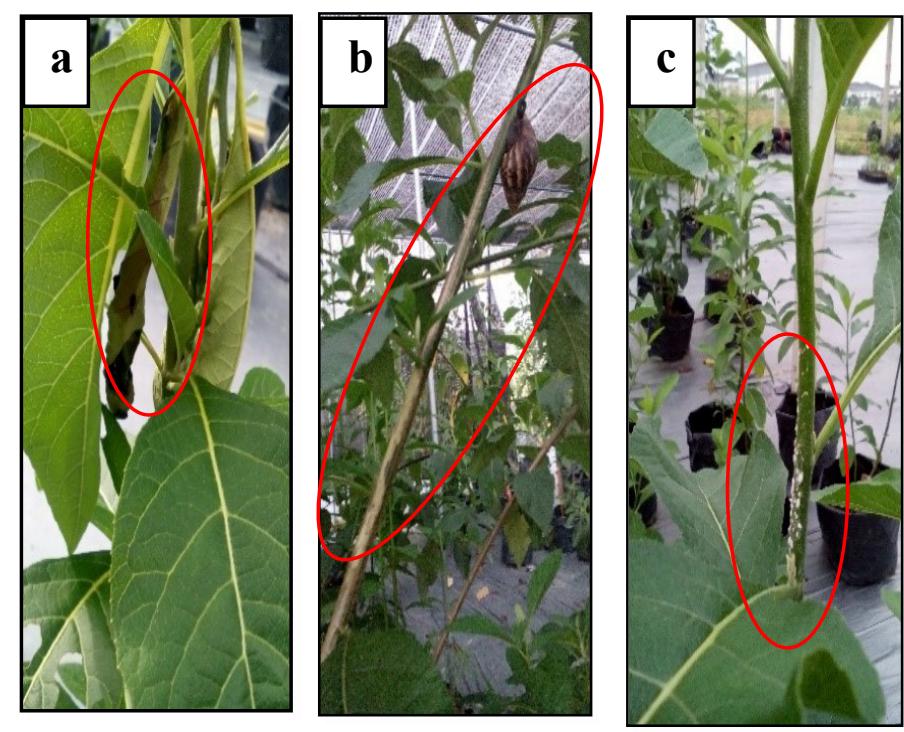

Figure 6. The main pests attacked on $V$. amygdalina: a) Caterpillars. b) Snail and c) Mealy bugs. Pictures taken from Field 15, Universiti Putra Malaysia, Serdang, Selangor.

The presence of bitter taste in $V$. amygdalina protects it from the vagaries of animals, insects and microbes, whereby the total area of leaf that is susceptible to insect attack ranges from 0.2-12\% (Akachuku, 2001). Most of the pests that usually attack this herb are Coleoptera curculionidae, weevil Lixus camerunus and Zonocerus variegates which utilize it as a source of protein (Eluwa, 1979). In addition, other pest species such as thrips, aphids, ants, white flies, Empoasa spp., Sphearocoris annulus, Fabricius spp., Ptyelus grossus, Polyclaeis spp. and Xanthochelus vulneratus have been reported to attack $V$. amygdalina (Ucheck Fomum, 2004) besides caterpillars, snails ad mealy bugs (Figure 6). Spraying the plants with insecticide such as Sherpa plus at $100 \mathrm{~mL}$ per $100 \mathrm{~L}$ applied at four weeks after planting has been reported to control insect infestation (Musa et al., 2011). A homemade organic pesticide using the ingredients including garlic, chillies, water, cooking oil and detergent could be also applied on the plants to control pests at the rate of $100 \mathrm{~mL}$ per $1.5 \mathrm{~L}$. While, other pest such as snails could be controlled by applying the Siputox around the field plot.

\section{Postharvest handlings}

\subsection{Drying and storage}

The information of postharvest handlings on $V$. amygdalina is still lacking. However, drying is a good method of preservation for $V$. amygdalina leaves. The drying temperature at $60^{\circ} \mathrm{C}$ within $24 \mathrm{hrs}$ is suitable to maintain the physical and chemical properties of $V$. amygdalina leaves (Akani et al., 2017). The removal of moisture during drying process minimizes enzymemediated deteriorative reactions, thus increasing shelf life of herb (Doymaz, 2005). Besides, drying process could kill the bacteria resulting in a decrease in heatstable enzymes at high temperatures hence reducing the bacterial contamination (Joanne et al., 2014). The microbial contamination could be reduced and prevented if $V$. amygdalina leaves are processed, packaged and stored aseptically. Maintenance of strict hygiene practices during processing and drying is important to produce dehydrated herbs with good microbial quality and extend shelf life (Akani et al., 2017). With regards to the storage of fresh leaves, the temperature of $5^{\circ} \mathrm{C}$ and storage period 1-6 months could stabilize the content of phytochemicals such as soft resin, alpha and iso-alpha acids in $V$. amygdalina as compared to $27^{\circ} \mathrm{C}$ (Ejoh et al., 2014). While, the losses in beta carotene, vitamins, oxalate and mineral content were found when $V$. amygdalina leaves were stored at $-4^{\circ} \mathrm{C}$ for 4 weeks (Ejike and Ndukwu, 2017). For dried leaves, packing them in low-density polyethylene (LDPE) packaging material until 12 weeks at room temperature could be recommended as it enables to stabilize the phytochemicals mainly total phenolic and flavonoid content in this herb.

\section{New direction of $V$. amygdalina cultivation in Malaysia}

Consumption and cultivation of $V$. amygdalina should be encouraged based on its nutritional value as well as its medicinal properties. V. amygdalina has only recently been cultivated from its natural habit of growing wild in Malaysia. It is used traditionally for the treatment 
of diabetes mellitus and hypertension, however no commercial product has successfully been developed (Atangwho et al., 2013). It has been classified by farmers as a multipurpose fodder tree with high biomass yield, easy propagation, high adaptability and compatibility with other crops as it does not compete for soil nutrients or moisture but instead helps to improve soil fertility and growth of perennial crops (Mekoya et al., 2008). Indeed, there is increased global awareness on the importance of $V$. amygdalina as a medicinal plant and many researchers and food processors are capitalizing on the potentials of its extract and phytochemicals in order to optimize their exploitation for disease treatment (Ejike and Ndukwu, 2017).

Besides using this herb for human consumption, $V$. amygdalina can also be used in animal feeds. Due to its high content of crude protein, it also was found to be a good source of protein for animals for normal growth and high milk production (Nwaoguikpe, 2010). While, addition of molasses to $V$. amygdalina (ratio 5:12) could reduce the bitterness of the plant and improve the palatability and acceptance by the rumen microbes (Yeap et al., 2010).

$V$. amygdalina is also safe to be consumed as food or herbal medicine at lower concentration without plausible toxicity to body organs and tissues of humans as it also supplies useful nutrients to animals (Imaga and Bamigbetan, 2013; Oyeyemi et al., 2018).

\section{Conclusion}

In conclusion, $V$. amygdalina is a multipurpose plant which possesses many uses, benefits and bioactivities. Along with its health promoting effect, it would be a good advantage if this plant can be turned into beneficial health products as it has little side effects. With its high survival ability to survive in any environmental condition, it would be less of a problem to cultivate this plant in large scale planting while applying proper and suitable agronomic practices for high yield of phytochemicals. Not only restricted to health products, this plant can also use to manufacture organic pesticides, organic fertilizers and even can be incorporated into feeds for the animals. Further studies and research on agronomic practices of $V$. amygdalina would add more information and develop new technologies to further promote this herb as a potential source of new products in enhancing the health and wellbeing of humans as well as for the livestock industry.

\section{Conflict of Interest}

The authors report no declaration conflict of interest.

\section{Acknowledgements}

The authors would like to express gratitude to the Ministry of Higher Education Malaysia for the financial support provided under the Fundamental Research Grant Scheme (FRGS) Grant, Project Number: 5524627.

\section{References}

Adekunle, A.A. (2002). Ethno botanical studies of some medicinal plants from Lagos State of Nigeria. Nigeria Journal of Botany, 12, 35-42.

Akachuku, C.O. (2001). Growth of bitter leaf (Vernonia amygdalina, Del. compositeae) and the nutritive values of its processed and unprocessed leaves. Discovery and Innovation, 13, 227-233. https:// doi.org/10.4314/dai.v13i3.15616

Akah, P.A. and Ekekwe, R.K. (1995). Ethnopharmacology of some Asteraceae family used in Nigerian traditional medicine. Fitoterapia, 66, 351 -355 .

Akani, N.P., Jumbo, B. and Nwankwo, C.E. (2017). Effect of drying temperatures on mineral composition and bacterial populations of Vernonia amygdalina (Bitter leaf). Research Journal of Food Science and Quality Control, 3(2), 39-49.

Alabi, D.A., Oyero, I.A., Jimoh. and Amusa, N.A. (2005). Fungitoxic and phytotoxic effect of Vernonia amygdalina (L), Bryophyllum pinnantus Kurz Ocimum gratissimum (Closium) L. and Eucalyptna globules (Caliptos) Labill water extracts on cowpea and cowpea seedling pathogens in Ago-Iwoye, South Western Nigeria. World Journal of Agricultural Sciences, 1, 70-75.

Atangwho, I.J., Edbung, G.E., Ahmad, M., Yam, M.F. and Asmawi, M.Z. (2013). Antioxidant versus antidiabetic properties of leaves from Vernonia amygdalina Del. growing in Malaysia. Journal of Food Chemistry, 141(4), 3428-3434. https:// doi.org/10.1016/j.foodchem.2013.06.047

Ayoola GA, Coker HAB, Adesegun S.A., Adepoju-Bello A.A., Obaweva K., Ezennia E.C. and Atangbayila T.O. (2008). Phytochemical screening and antioxidant activities of some selected medicinal plants used for malaria therapy in Southwestern Nigeria. Tropical Journal of Pharmaceutical Research, 7, 1019-1024.

Chagnon, M. (1984). General pharmacological inventory of medicinal plants of Rwanda. Journal of Ethnopharmacology, 12(3), 239-251. https:// doi.org/10.1016/0378-8741(84)90053-9

Clayton, D.H. and Wolfe, N.D. (1993). The adaptive significance of self-medication. Trends in Ecology and Evolution, 8(2), 60-63. https:// 
doi.org/10.1016/0378-8741(84)90053-9

Doymaz, L. (2005). Dry behavior of green beans. Journal of Food Engineering, 69(2), 161-165. https://doi.org/10.1016/j.jfoodeng.2004.08.009

Ejike, C.E. and Ndukwu, M.C. (2017). Pre-harvest and post-harvest factors affecting bioactive compounds from Vernonia amygdalina (Del.). Research Journal of Medicinal Plants, 11(2), 32-40. https:// doi.org/10.3923/rjmp.2017.32.40

Ejoh, R.A., Djuilkwo, V., Gouado, I. and Mbofung Carl, M. (2007). Effect of the method of processing and preservation on some quality parameters of three non -conventional leafy vegetables. Pakistan Journal of Nutrition, 6(2), 128-133. https://doi.org/10.3923/ pjn.2007.128.133

Eluwa, M.C. (1979). Biology of Lixus-Camerunus Kolbe (Coleoptera Curculionidae) a major pest of the edible Vernonias Compositae in Nigeria. Revue de Zoologie Africaine, 93, 223-240.

Enikuomehin, O.A., Ikotun, T. and Ekpo, E.J.A. (1998). Evaluation of ash from some tropical plants of Nigeria for the control of Sclerotium rolfsii Sacc. on wheat (Triticum aestivum L.). Mycopathoologia, 142 (2), $\quad$ 81-87. https://doi.org/10.1023/ A: 1006926817580

Erasto, P., Grierson, D.S. and Affolaya, A.J. (2007a). Antioxidant constituents in Vernonia amygdalina leaves. Pharmaceutical Biology, 45(3), 195-199. https://doi.org/10.1080/13880200701213070

Erasto, P., Grierson, D.S. and Afolaya, A.J. (2007b). Evaluation of antioxidant activity and the fatty acid profile of the leaves of Vernonia amygdalina growing in South Africa. Food Chemistry, 104(2), 636-642.

https://doi.org/10.1016/ j.foodchem.2006.12.013

Etkin, N.L. (2002). Local knowledge of biotic diversity and its conservation in rural Hausaland, Northern Nigeria. Economic Botany, 56, 73-88. https:// doi.org/10.1663/0013-0001(2002)056

[0073:LKOBDA]2.0.CO;2

Farombi, E.O. (2003). African indigenous plants with chemotherapeutic potentials and biotechnological approach to the production of bioactive prophylactic agents. African Journal of Biotechnology, 2, 662671. https://doi.org/10.5897/AJB2003.000-1122

Farombi E.O. and Owoeye, O. (2011). Antioxodant and chemopreventive properties of Vernonia amygdalina and Garcinia biflavonoid. International Journal of Environmental Research and Public Health, 8(6), 2533-2555. https://doi.org/10.3390/ijerph8062533

Fasuyi A.O. (2006). Nutritional potentials of some tropical vegetables leaf meal, chemical characterization and functional properties. African Journal of Biotechnology, 5(1), 49-53.

Francis, M. (2015). The amazing health benefits of Bitter leaf (Vernonia Amygdalina). The Nature's Farmacy. Retrieved from The Natures Farmacy website: https://www.thenaturesfarmacy.com/health-benefitsof-bitter-leaf-vernonia-amygdalina

Ghamba, P.E., Balla, H., Goje, L.J., Halidu, A. and Dauda, M.D. (2014). In vitro antimicrobial activities of Vernonia amygdalina on selected clinical isolates. International Journal of Current Microbiology and Applied Sciences, 3(4), 1103-1113.

Grubben, G.J.H. (2004). PROTA Volume 2 Vegetables, PROTA Foundation, p. 543 - 544. Retrieved from website: http:// books.google.com.my/books? id=6jrlyOPfr24C\&pg=PA543\&dq=Vernonia + amygd alina\&hl=en\&sa $=$ X\&ei=EoNTUbXLC8XIrQeW5Y Ew\&redir_esc $=\mathrm{y} \# \mathrm{v}=$ onepage $\& \mathrm{q}=\mathrm{Vernoni}$

Hamill, F.A., Apio, S., Murbiru, N.K., Mosango, M., Bukenya-Ziraba, R., Maganyi, O.W. and Soejarto, D.D. (2000). Traditional herbal drugs of southern Uganda. Journal of Ethnopharmacology, 70(3), 281300. https://doi.org/10.1016/S0378-8741(00)00180$\mathrm{X}$

Hamzah, R.U., Jigam, A.A., Makun, H.A. and Egwin, E.C. (2013). Antioxidant Properties of Selected African Vegetables, Fruits and Mushrooms: A Review. Intech, 9, 203-250. https:// doi.org/10.5772/52771

Ho, W.Y., Liang, W.S., Yeap, S.K., Beh, B.K. and Yousr, A.H.N. (2012). In vitro and in vivo antioxidant activity of Vernonia amygdalina water extracts. African Journal of Biotechnology, 11(17), 4090-4094.

Huffman, M.A., Gotoh, S., Turner, L.A., Hamai, M. and Yoshida, K. (1997). Seasonal Trends in intestinal nematode infection and medicinal plant use among chimpanzees in the Mahale Mountains, Tanzania. Primates, 38(2), 111-125. https://doi.org/10.1007/ BF02382002

Huffman, M.A. and Seifu, M. (1989). Observation on the illness and consumption of a possibly medicinal plant Vernonia amygdalina (Del.), by a wild chimpanzee in the Mahale Mountains National Park, Tanzania. Primates, 30(1), 51-63. https:// doi.org/10.1007/BF02381210

Huffman, M.A., Page, J.E., Sukhdeo, M.V.K., Gotoh, S., Kalunde, M.S. and Towers, G.H.N. (1996). Leaf swallowing by chimpanzees: a behavioral adaptation for the control of strong nematode infections. International Journal of Primatology, 72(4), 475- 
503. https://doi.org/10.1007/BF02735188

Ifon, E.T. and Bassir, O. (1979). The nutritive value of some Nigerian leafy green vegetables- Part 1: Vitamin and mineral contents. Journal of Food Chemistry, 4(4), 263-267. https:// doi.org/10.1016/0308-8146(79)90014-1

Igile, G., Oleszek, W. and Jurzysta, M. (1995). Vernoniosides D and E, two novel saponins from Vernonia amygdalina. Journal of Natural Products, 58(9), 1438-1443. https://doi.org/10.1021/ np50123a016

Igile, G., Oleszek, W., Jurzysta, M., Burda, S., Fafunso, M. and Fasanmade, A.A. (1994). Flavonoids fom Vernonia amygdalina and their antioxidant activities. Journal of Agricultural and Food Chemistry, 42(11), 2445-2448. https://doi.org/10.1021/jf00047a015

Imaga, N.O.A. and Bamigbetan, D.O. (2013). In vivo biochemical assessment of aqueous extracts of Vernonia amygdalina (Bitter leaf). International Journal of Nutrition and Metabolism, 5(2), 22-27.

Iwalewa, E.O., Adewunmi, C.O., Omisore, N.O., Adebanji, O.A., Azike, C.K., Adigun, A.O., Adesina, O.A. and Olowoyo, O.G. (2005). Pro- and antioxidant effects and cytoprotective potentials of nine edible vegetables in Southwest Nigeria. Journal of Medicinal Food, 8(4), 539-544. https:// doi.org/10.1089/jmf.2005.8.539

Jisaka, M., Ohigashi, H., Takegawa, K., Hirota, M., Irie, R., Huffman, M.A. and Koshimizu, K. (1993). Steroid glucosides from Vernonia amygdalina, a possible chimpanzee medicinal plant. Phytochemistry, 34(2), 409-413. https:// doi.org/10.1016/0031-9422(93)80019-O

Jisaka, M., Ohigashi, H., Takegawa, K., Huffman, M.A. and Koshimizu, K. (1993). Antitumoral and antimicrobial activities of bitter sesquiterpene lactones of Vernonia amygdalina, a possible medicinal plant used by wild chimpanzees. Bioscience, Biotechnology and Biochemistry, 57(5), 833-834. https://doi.org/10.1271/bbb.57.833

Joanne, W., Linda, S. and Chris, W. (2014). Food-borne and waterborne diseases. Prescott's Microbiology, 9th ed., p. 915-924. New York: McGraw Hill Education.

Kadiri, O. and Olawoye, B. (2016). Vernonia amygdalina: An underutilized vegetable with nutraceutical potentials- A review. Turkish Journal of Agriculture Food Science and Technology, 4(9), 763-768. https://doi.org/10.24925/turjaf.v4i9.763768.570

Kambizi, L. and Afolayan, A.J. (2001). An ethnobotanical study of plants used for the treatment of sexually transmitted diseases (njovhera) in Guruve District, Zimbabwe. Journal of Ethnopharmacology, 77(1), 5-9. https:// doi.org/10.1016/S0378-8741(01)00251-3

Kasalo, W.K. and Temu, A.B. (2008). Tree species selection for buffer zone agroforestry: The case of Budongo Forest in Uganda. International Forestry Review, 10, 52-64. https://doi.org/10.1505/ ifor.10.1.52

Kayode, J. (2004). Eco-physiological studies on Vernonia amygdalina in Ekiti State, Nigeria. Pakistan Journal of Scientific and Industrial Research, 47, 227-230.

Khalafalla, M.M., Abdellatef, E., Daffalla, H.M., Nassrallah, A.A., Aboul-Enein, K.M., Lightfoot, D.A., Cocchetto, A. and El-Shemy, H.A. (2009). Antileukemia activity from root cultures of Vernonia amygdalina. Journal of Medicinal Plants Research, 3, 556-562.

Kiguba, R., Ononge, S., Karamagi, C. and Bird, S.M. (2016). Herbal medicine use and linked suspected adverse drug reactions in a prospective cohort of Ugandan inpatients. BMC Complement. Alternative Medicinal, 16, 145. https://doi.org/10.1186/s12906016-1125-x

Komlaga, G., Agyare, C., Dickson, R.A., Mensah, M.L., Annan, K. and Loiseau, P.M. (2015). Medicinal plants and finished marketed herbal products used in the treatment of malaria in the Ashanti region, Ghana. Journal of Ethnopharmacology, 172, 333346. https://doi.org/10.1016/j.jep.2015.06.041

Koshimizu, K., Ohigashi, H. and Huffman, M.A. (1994). Use of Vernonia amygdalina by wild chimpanzee: Possible roles of its bitter and related constituents. Journal of Physiology and Behavior, 56(6), 12091216. https://doi.org/10.1016/0031-9384(94)90368-9

Kupchan, S.M., Hemingway, R.J., Karim, A. and Werner, D. (1969). Tumor inhibitors. XLVII. Vernodalin and vernomygdin, two new cytotoxic sesquiterpene lactones from Vernonia amygdalina del. Journal of Organic Chemistry, 34(12), 39083911. https://doi.org/10.1021/jo01264a035

Luo, X., Jiang, Y., Fronczek, F.R., Lin, C., Izevbigie, E.B. and Lee, K.S. (2011). Isolation and structure determination of a sesquiterpene lactone (vernodalinol) from Vernonia amygdalina extracts. Journal of Pharmaceutical Biology, 49(5), 464-470. https://doi.org/10.3109/13880209.2010.523429

Marles, R.J. and Farnsworth, N.R. (1995). Antidiabetic plants and their active content. Phytomedicines, 2(2), 137-189. https://doi.org/10.1016/S0944-7113(11) 80059-0 
Mekoya, A., Oosting, S.J., Fernandez-Rivera, S. and Van der Zijpp, A.J. (2008). Multipurpose fodder trees in the Ethiopian highlands: Farmers' preference and relationship of indigenous knowledge of feed value with laboratory indicators. Agricultural Systems, 96(1 -3), 184-194. https://doi.org/10.1016/ j.agsy.2007.08.001

Moshi, M.J., Otieno, D.F., Mbabazi, P.K. and Weisheit, A. (2010). Ethnomedicine of the Kagera Region, North western Tanzania. Part 2: The medicinal plants used in Katoro Ward, Bukoba District. Journal of Ethnobiology and Ethnomnedicine, 6, 19. https:// doi.org/10.1186/1746-4269-6-19

Munaya, C. (2013). Bitter leaf-based extracts cures hepatitis co-inferation and others. London: The Guardian Newspaper. Published on July 25, 2013.

Musa, A., Ogbadoyi, E.O., Oladiran, J.A, Ezenwa, M.I.S. and Akanya, H.O. (2011). Effect of reproductive phase on some micronutrients, anti-nutrients and toxic substances in Vernonia amygdalina grown in Minna, Niger state, Nigeria. African Journal of Plant Science, 599, 525-530.

Ndaeyo, N.U. (2007). Assessing the contributions of homestead farming to food security in a developing economy: a case study of Southeastern Nigeria, Journal of Agriculture and Social Sciences, 3, 11-16.

Nduagu, C., Ekefan, E.J. and Nwankiti, A.O. (2008). Effect of some crude plant extracts on growth of Colletotrichum capsici (Synd) Butler and Bisby, causal agent of pepper anthracnose. Journal of Applied Biosciences, 6, 184-190.

Nwaoguikpe, R.N. (2010). The effect of extract of bitter leaf (Vernonia amygdalina) on blood glucose levels of diabetic rats. International Journal of Biology and Chemical Sciences, 4(3), 729-729. https:// doi.org/10.4314/ijbcs.v4i3.60500

Oboh, G. (2005). Effect of blanching on the antioxidant properties of some tropical green leafy vegetables. LWT-Food Science and Technology, 38(5), 513-517. https://doi.org/10.1016/j.lwt.2004.07.007

Oboh, G. and Akindahunsi, A.A. (2004). Change in the ascorbic acid, total phenol and antioxidant activity of sun-dried commonly consumed green leafy vegetables in Nigeria. Nutrition and Health, 18(1), 29 -36. https://doi.org/10.1177/026010600401800103

Oboh, F.O.J. and Enobhayisobo, EL. (2009). Effect of aqueous extract of Vernonia amygdalina leaves on plasma lipids of hyperlipidemia adult male albino New Zealand rabbits. African Scientist, 10(4), 203213.

Odukoya, O.A., Inya-Agha, S.I., Segun, F.I., Sofidiya, M.O. and Ilori, O.O. (2007). Antioxidant activity of selected Nigerian green leafy vegetables. American Journal of Food Technology, 2, 169-175. https:// doi.org/10.3923/ajft.2007.169.175

Ogbebor, N.O., Adekunle, A.T. and Enobakhare, D.A. (2007). Inhibition of Colletrotrichum gloeosporioides (Penz) Sac. Causal organism of rubber (Hevea brasiliensis Muell. Arg.) leaf spot using plant extracts. African Journal of Biotechnology, 6, 213218.

Ohigashi, H., Takagaki, T., Koshimizu, K., Watanabe, K., Kaji. M, Hoshino, J., Nishida, T., Huffman, M.A., Takasaki, H., Jato, J. and Muanza, D.N. (1991). Biological activities of plant extracts from tropical Africa. African Study Monographs, 12, 201-210.

Okigbo, R.N. and Emoghene, A.O. (2003). Effect of leaf extracts of three plant species on Mycosphaerella fijiensis Morelet, the causal organism of black sigatoka disease of banana (Musa acuminata). Nigerian Society for Plant Protection Journal, 20, 101-110.

Oseni, K. and Babatunde, O. (2016). Vernonia amygdalina: An Underutilized Vegetables with Nutraceutical Potentials - A Review. Turkish Journal of Agriculture - Food Science and Technology, 4(9), 763-768. https://doi.org/10.24925/turjaf.v4i9.763768.570

Owoeye, O., Yousuf, S., Akhtar, M.N., Qamar, K., Dar, A. and Farombi, E.O. (2010). Another anticancer elemanolide from Vernonia amygdalina Del. International Journal of Biological and Chemical Sciences, 4, 226-234. https://doi.org/10.4314/ ijbcs.v4i1.54250

Owolabi, M.A., Jaja, S.I., Oyekanmi, O.O. and Olatunji, J. (2008). Evaluation of the Antioxidant Activity and Lipid Peroxidation of the Leaves of Vernonia amygdalina. Journal of Complementary and Integrative Medicine, 5(1), 21. https:// doi.org/10.2202/1553-3840.1152

Owolade, O.F., Amusa, A.N. and Osikanlu, Y.O.K. (2000). Efficacy of certain indigenous plant extracts against seed-borne infection of Fusarium moniliforme of maize (Zea mays L.) in South Western Nigeria. Cereal Research Communications, 28, 323-327.

Oyeyemi, I.T., Akinlabi, A.A., Adewumi, A., Aleshinloye, A.O. and Oyeyemi, O.T. (2018). Vernonia amygdalina: A folkloric herb with antihelmitic properties. Beni-Suef University Journal of Basic and Applied Sciences, 7(1), 43-49. https:// doi.org/10.1016/j.bjbas.2017.07.007

Quasie, O., Zhang, Y., Zhang, H., Luo, J. and Kong, L. (2016). Four new steroid saponins with highly 
oxidized side chains from the leaves of Vernonia amygdalina. Journal of Phytochemistry Letters, 15, 16-20. https://doi.org/10.1016/j.phytol.2015.11.002

Quattrocchi, U. (1999). CRC World Dictionary of Plant Names: Common Names, Scientific Names, Eponyms. Synonyms, and Etymology. $1^{\text {st }}$ ed., p. 640. US: CRC Press.

Riley, H. (1963). Families of flowering plants of Southern Africa., p. 170. US: University of Kentucky Press.

Taiwo, O., Xu, H.X. and Lee, S.F. (1999). Antibacterial activities of extracts from Nigerian chewing sticks. Phytotherapy Research, 13(8), 675-679. https:// doi.org/10.1002/(SICI)1099-1573(199912) $13: 8<675::$ AID-PTR513>3.0.CO;2-X

Ucheck Fomum, F. (2004). Vernonia amygdalina Delile. In Grubben, G.J.H. and Denton, O.A. (ed.). Record from PROTA4U. PROTA (Plant Resources of Tropical Africa. Wageningen, Netherlands. <http:// www.prota4u.org/search.asp>.

Udochukwu, U., Omeje, F.I., Uloma, I.S., Oseiwe, F.D. (2015). Phytochemical analysis of Vernonia amygdalina and Ocimum gratissimum extracts and their antibacterial activity on some drug resistant bacteria. American Journal of Research Communication, 3(5), 225-235.

Usunobun, U. and Ngozi, O. (2016). Phytochemical analysis and proximate composition of Vernonia amygdalina. International Journal of Scientific World, 4(1), 11. https://doi.org/10.14419/ ijsw.v4i1.5845

Vlietinck, A.J., Van Hoof, L., Totte, J., Lasure, A., Vanden Berghe, D., Rwangabo, P.C. and Mvukiyumwami, J. (1995). Screening of hundred Rwandese medicinal plants for antimicrobial and antiviral properties. Journal of Ethnopharmacology, 46(1), 31-47. https://doi.org/10.1016/0378-8741(95) 01226-4

Wu, Y.Y., Li, W., Xu, Y., Jin, E.H. and Tu, Y.Y. (2011). Evaluation of the antioxidant effects of four main theaflavin derivatives through chemiluminescence and DNA damage analyses. Journal of Zhejiang University Science B, 12, 744-751. https:// doi.org/10.1631/jzus.B1100041

Yamagishi, S. and Matsui, T. (2011). Nitric oxide, a Janus-faced therapeutic target for diabetic microangiopathy-Friend or foe? Pharmacology Research, 64(3), 187-194. https://doi.org/10.1016/ j.phrs.2011.05.009

Yeap, S.W., Ho, W.Y., Beh, B.K., Liang, W.S., Ky, H., Noaman Yousr, A.H. and Alitheen, N.H. (2010). Vernonia amygdalina, an ethnoveterinary and ethnomedical used green vegetable with multiple bioactivities. Journal of Medicinal Plants Research, 4(25), 2787-2812.

Yineger, H. and Yewhalaw, D. (2007). Traditional medicinal plant knowledge and use by local healers in Sekoru District, Jimma Zone, Southwestern Ethiopia. Journal of Ethnobiology and Ethnomedicine, 3, 24. https://doi.org/10.1186/17464269-3-24 